\title{
Improvements in primary care skills and knowledge with a vocational training program: a medical student's perspective
}

Advances in Medical Education and Practice

15 September 2017

Number of times this article has been viewed

\author{
Anita Ghosh \\ Diya Kapila \\ Trisha Ghosh \\ Faculty of Medicine, Imperial College \\ London, Kensington, London, UK
}

\section{Dear editor}

We read with great interest, the article by Djalali et al evaluating the impact of a training program during residency, targeted toward primary care. ${ }^{1}$ This resonated with us from a medical student's perspective as we are fortunate enough to have a similar program at medical school. Although the article states that future career choices are more likely to be determined during residency, we believe that this can be nurtured earlier through knowledge and early exposure.

Within the UK, we too face the same challenges associated with primary care. In 2015, along with core psychiatry, general practice had the lowest number of applications per training post than any other speciality. ${ }^{2}$ Additionally, in 2016, a review by the King's Fund showed that the majority of current trainees do not intend to continue full-time work after completing 5 years post-certification. ${ }^{3}$ We agree that increasing exposure to primary care is imperative, and we have explored some of the possible ways to do so.

The Integrated Clinical Apprenticeship (ICA) was piloted at Imperial College London last year. Its aims were to incorporate continuity of care and patient-centered care as core learning objectives, using primary care practices as the base. Year 5 students are assigned to specific general practices and patients. Every Thursday, students clerk and examine different presenting complaints, emulating the GP's role. There are further opportunities to explore patient cases and receive feedback regarding their own performance. Overall, students have stated that they have gained confidence with their interpersonal skills, which supports the findings in the article.

The article postulates that a career in primary care correlates with prior exposure to this field. Currently, within the UK, the majority of graduates will undergo a 4-month GP placement during their foundation years. However, there has been no improvement in the number of applications. The North West of England Foundation School has recently begun a trial program called Longitudinal Integrated Foundation Training, not dissimilar to the ICA in terms of its structure and aims. ${ }^{4}$ Trainees attend a general practice for 1 week every month throughout their training, which improves their GP exposure.

Perhaps there is also scope for further change within the curriculum, notably in GP attitudes toward student teaching. GP placement feedback is purportedly linked with the enthusiasm and motivation for teaching given by the GP; a GP who solely consults the patient and does not involve the student will inevitably create a negative learning environment. The range of GP experiences is vast, with large geographical variations. 
Furthermore, the practical skills assimilated during GP placements are highly divergent: some students have the opportunity to shadow a variety of clinics and partake in practical procedures, including minor surgery, compared to a single clinic opportunity for other students. This is unarguably going to influence student satisfaction and will render decreased student interest in primary care. The implementation of GP standardization throughout UK medical schools along with longitudinal programs will allow for greater awareness and enthusiasm for primary care medicine.

\section{Disclosure}

The authors report no conflicts of interest in this communication.

\section{References}

1. Djalali S, Tandjung R, Rosemann T, Markun S. Improvements in primary care skills and knowledge with a vocational training program - a pre-post survey. Adv Med Educ Pract. 2017;8;541-549.

2. bmjcareers [homepage on the Internet]. Kennedy C. Specialty training applications for entry in 2016: competition ratios and the application process. BMJ Careers; 2015. Available from: http://careers.bmj.com/careers/ advice/Specialty_training_applications_for_entry_in_2016\%3A_competition_ratios_and_the_application_process. Accessed September 5, 2017.

3. kingsfund.org.uk [homepage on the Internet]. Baird B, Charles A, Honeyman M, Maguire D, Das P. Increasing demands on general practice. The King's Fund; 2016. Available from: https://www.kingsfund.org.uk/ publications/pressures-in-general-practice. Accessed September 5, 2017.

4. nwpgmd.nhs.uk [homepage on the Internet]. North West Foundation Training Programmes, 2017. Health Education England (North Western Deanery, NHS). Available from: https://www.nwpgmd.nhs.uk/ f1-f2-training-programmes-2014-2016. Accessed September 5, 2017. 


\section{Author's reply Sima Djalali}

Institute of Primary Care, University of Zurich, University Hospital of Zurich, Zurich, Switzerland

Correspondence: Sima Djalali

Institute of Primary Care, University of Zurich, University Hospital of

Zurich, Pestalozzistrasse 24, CH-809I Zurich, Switzerland

Email sima.djalali@usz.ch

\section{Dear editor}

We appreciate Ghosh et al's feedback and agree with them.

Time spent in primary care during residency (average period of time/timing at the beginning or toward the end of education) is an easy-to-measure and easy-to-compare variable. That is why many studies rely on this variable. ${ }^{1-4}$

In contrast, content quality of training programs including GP attitude toward student teaching - is much more difficult to define and to measure, though it might be the key to evoke awareness and enthusiasm for primary care medicine.

The implementation of GP standardization throughout medical schools (not only in the UK) along with longitudi- nal programs would make it a lot easier to develop quality indicators allowing to measure and compare content quality of training programs.

Unfortunately, in Switzerland, we have not reached this point yet. The evaluation of our vocational training program in Zurich was only a first step.

\section{Disclosure}

The author reports no conflicts of interest in this communication.

\section{References}

1. Pfarrwaller E, Sommer J, Chung C, Maisonneuve H, Nendaz M, Junod Perron N, Haller DM. Impact of interventions to increase the proportion of medical students choosing a primary care career: a systematic review. J Gen Internal Med. 2015;30(9):1349-1358.

2. Zinn WM, Sullivan AM, Zotov N, Peters AS, Connelly MT, Singer JD, Block SD. The effect of medical education on primary care orientation: results of two national surveys of students' and residents' perspectives. Acad Med. 2001;76(4):355-365.

3. Stordeur S, Leonard C. Challenges in physician supply planning: the case of Belgium. Hum Resour Health. 2010;8:28.

4. Tandjung R, Senn O, Marty F, Krauss L, Rosemann T, Badertscher N. Career after successful medical board examination in general practice - a cross-sectional survey. Swiss Med Wkly. 2013;143:w13839.

Dove Medical Press encourages responsible, free and frank academic debate. The content of the Advances in Medical Education and Practice 'letters to the editor' section does not necessarily represent the views of Dove Medical Press, its officers, agents, employees, related entities or the Advances in Medical Education and Practice editors. While all reasonable steps have been taken to confirm the content of each letter, Dove Medical Press accepts no liability in respect of the content of any letter, nor is it responsible for the content and accuracy of any letter to the editor.

\section{Publish your work in this journal}

Advances in Medical Education and Practice is an international, peerreviewed, open access journal that aims to present and publish research on Medical Education covering medical, dental, nursing and allied health care professional education. The journal covers undergraduate education, postgraduate training and continuing medical education including emerging trends and innovative models linking education, research, and health care services. The manuscript management system is completely online and includes a very quick and fair peer-review system. Visit http://www.dovepress.com/testimonials.php to read real quotes from published authors. 